\title{
How Realistic is the China-Pakistan-Iran Economic Corridor?
}

Abstract:

The economic and political influence of China in the Asian region is growing amidst global geopolitical challenges. Economic corridors such as the new Silk Road have been identified as enablers of strategic growth and economic development in a context of significant political instability and conflict. Beijing's strategic approach and the importance of Pakistan and Iran to its aspiration to realise China's dream through its Belt and Road Initiative is examined in this comparative study. The raising role of China in the region and its engagement with Iran and Pakistan and the part that these two countries can play need careful attention. Political and economic joint interests have brought together these three countries with significant links to China's corridor economic and energy projections. But the future of the partnership is very fragile as it is characterised by historical hostilities between Iran and Pakistan that can act as a major hurdle on China's ability to progress. In addition, the economic and trade figures show an un-balanced relationship that clearly favours Chinese interests. The BRI initiative and the Chinese plans for those territories by today are not very clear, they remain as blurry as any long-term crisis that characterise fragile and complex international alliances.

Keywords: CPEC, BRI, Geopolitics, Pakistan, Iran, China

Word count: 72231 


\section{Introduction}

The Belt and Road Initiative (BRI) has led to new economic, diplomatic, and political dynamics in the central and Southwest Asian region. Pakistan and Iran have emerged as compelling economic players in China's ambition to progress with its economic corridor. Beijing considers these two countries to be a "String of Pearls" where to develop its economic and security strategy and where it can progress as a regional and global economic power. After the consolidation of the BRI plan, this String of Pearls would enable China to find a maritime Silk Road along the Indian Ocean Region (Ashraf 2017).

According to Khan (2014), the China-Pakistan-Iran triangle can be linked to Pakistan's long-standing rivalry with India and with Iran's protracted antagonism against the USA. Existing rivalries and conflict axes have acted as significant forces attracting Pakistan and Iran closer to Beijing on their quest for economic development and progress.

The nature and future of this relationship are an appealing area of research that offers insights on regional dynamics and associated challenges to China's BRI ambition. This paper aims to provide some critical insights that contribute to understand the origins of this potential partnership and its feasibility. The triangular economic and political dynamics and how they are unfolding are crucial areas of study due to their implications for the region's economic and political future. Interactions between the three states and their influence on bilateral and multilateral agreements are considered positive and valuable economic integration indicators. But some initial areas of concern emerge which lead us to question the formation of this triangle: i) Is the formation of an economic triangle between these countries a real option? ii) Will China be able to make real progress with its vision? A fundamental point to be considered is that these countries are faced with continuous tensions and conflicts that undermine their economic and political stability; a third question that arises is thus: iii) Would it be possible for China to engage both countries in its plans to consolidate the BRI? The outlined questions show the region's delicate balancing act and they put forward China's main challenges as it tries to progress with its regional approach in terms of economic integration. 
This research study seeks to address the outlined questions by examining China's economic and political influence in the region by exploring Beijing's strategic approach and the importance of Pakistan and Iran on its aspiration to realise its New Silk Road dream. The study offers a critical assessment of economic corridors' value and relevance as enablers of strategic growth and economic development in a context of significant instability and conflict (Ogunlana 2006). China's rising role in the region and its engagement with Iran and Pakistan, and the role these two countries can play need careful attention. Political and economic joint interests have brought together these countries with significant links to China's economic corridor and energy projections. The Chinese government seeks to address domestic and international pressures derived from its over-reliance on coal as its primary energy resource in parallel with the sharp decline in economic growth rates experienced since the 2008 Global Economic and Financial Crisis. But the partnership's future is fragile as it is characterised by historical hostilities between Iran and Pakistan that can be a significant hurdle to China's ability to progress with its economic corridor.

The rest of the paper is structured as follows: the next section reviews the main economic challenges faced by the Pakistani economy: the ensuing section discusses similar issues in relation to Iran; the fourth section measures the economic relationship between the three countries by using econometric tools whereas section 5 analyses the viability of the economic corridor between the three economies. These analyses will lead us to examine the geo-political challenge left in designing a China-Pakistan-Iran alliance (in Section 6), whereas a final section will conclude.

\section{Pakistan's Emerging Economy within the Context of Regional Rivalries}

Pakistan is a crucial actor in the current economic and political dynamics of the South Asian continent. The CPEC (China-Pakistan Economic Corridor) project appears to be the closest future trend for the country and it will shape the nation's main geopolitical and economic axes. This, on its own, will be as well-shaped by the always omnipresent India. There are significant worries regarding existing risks and conflicts between the two neighbours that could escalate at any moment. On the other hand, if the existing dynamics of conflict contention prevail, the challenges regarding political stability - that are of paramount importance to ensure that economic and developmental goals can be achieved - diminish significantly. 
But how do all these political and economic pieces fit together into this geostrategic puzzle? First of all, there is a need to highlight how the CPEC project fits into the global aspirations that embrace the Belt Road Initiative. China has unveiled a very ambitious project designed to gain geopolitical momentum across several continents and to counterbalance the Washington atmosphere influence. This project has created diverse interests amongst the different possible Belt Road receiving countries. However, it seems that China and Pakistan share mutual interests. Pakistan is part of the group of countries with a two-way capital matching approach, meaning that their real interest rates are high. Simultaneously, the adjusted lending costs of these countries are also higher than those associated with China (Wu and Pan 2019). In other words, Pakistan is part of China's list for target investments, and on the other hand, Pakistan is willing to get Chinese financing and to become part of the BRI, leading towards a potential symbiotic relationship.

According to the World Bank, Pakistan's GDP reached a value of 278,222 billion dollars in 2019 current Dollar terms. With decades of political insecurity and corruption, the country's economy has made it into the developing countries' low charts. On the other side, this same situation makes the country very attractive to China as it searches for competitive offers and conditions to establish the CPEC and its Belt and Road Initiative. The Asian titan seeks to widen potential economic policies that can be considered in the region's context as it tries to consolidate its position as a leading economic player. One of the main structural problems linked to both the underdevelopment of Pakistan's economy and its inherent political instability is explained by the magnitude of its informal economy and associated difficulties in quantifying its contribution to the national GDP. Informality has been a constant element in the historical trends of the Pakistani economy. Aslam (1998) found that in 30 years (1960-1990), the informal economy increased to almost $75 \%$ of GDP, by taking the log-ratios of the currency in circulation and of foreign currencies as the unit of measurement. The main factor that has helped explain the economic patterns linked to associated increases seems to be the tax burden. An updated research study developed by Khan and Khalil (2018) using a monetary approach method (currency demand) showed that the situation has worsened reaching a 91\% of informality in the years 2007-2008. With such a scenario, the appearance of the regularities and formalities behind the CPEC project entails a major societal, economic, and political change with its new future opportunities and challenges. Before introducing the changes and the potential of such a project it is of interest to briefly introduce one of the main key issues behind the BRI and the CPEC initiative, or even further, to any future country development: the energetic crisis and the infrastructural crisis that Pakistan faces. 
In addition, for many years Pakistan has been confronting a deep crisis in the electricity field with severe electricity and natural gas shortages, which led to the policy of forced load shedding in the country (Aized \& Al 2017). Several studies have found that shortages of electricity supply have been regular in urban areas lasting between 8 to 12 hours and up to 18 hours due to the mismatch between supply and demand. To add further complexities to the problem, Pakistan lacks the appropriate energy modelling tools and expertise that enables the integration of energy planning and energy policy formulation (Valasai, et al. 2017). With this context of unplanned energy policy, the country can benefit from any project that invests in infrastructure, and that contributes to the development of new and alternative energy sources. The outlined issues are already captured in the amount of investment foreseen in the CPEC that will be allocated to improve the country's energy system capacity by $61 \%$ of the total agreement contained in the 2014 early Plan announcements.

Moreover, if the projections materialise and work as expected, Pakistan might be able to address what is commonly known as 'Pakistan's Interminable Energy Crisis.' According to different national studies, this situation costs the country's economy between $2 \%$ to $2.5 \%$ of its annual GDP. Even in the early phases of the CPEC (namely in the years 2017-18), it was expected that the 2014 CPEC Plan would add 10,400MW to the Pakistani energy system. Up to $36 \%$ of CPEC funding is invested into infrastructure, transport, and communication. According to the Pakistani Planning Commission, the transport sector's poor performance costs on a yearly basis between $4 \%$ to $6 \%$ of its economy GDP due to the close connection between the existing infrastructure and economic development (Esteban 2016).

\section{China's Alliance amid tensions with India}

The other aspect of this project comes with the risks that such an alliance with China could trigger some resentment between Pakistan and its neighbour India. The Indo-Pakistani enmity goes back to the year 1947 when India's partition led to two independent dominion states (India and Pakistan), and since then, the relationship between the two nations has been quite unstable. The two countries have experienced periods of relative calm followed by severe conflict, with four wars on their shoulders and two Border States under dispute: Kashmir and Jammu. Most International Relations scholars, will argue that the two countries follow a frozen conflict relations dynamic (Sumit et al. 2019). This research study does not focus on the countries' mere political 
aspects; however, this paper uses such a lens to understand the outlined dynamics and their implications to the CPEC. Despite the economic advances envisioned in the CPEC project, economic stability will remain attached to Pakistan's neighbouring relations' political uncertainty, which poses itself one of the main weaknesses of the task ahead of China as it aims at the corridor success. Nonetheless, there are historical examples of reconciliation and rapprochement between the two countries such as the 1999 Lahore Declaration or the Agra summit of 2001, with both political initiatives searching for peace (Ibid). On the political economy side and in terms of the development of relations between India and Pakistan, this could also be seen as an opportunity to confer to Pakistan the role of a new important and successful partner in the region. Current global challenges derived from the global health crisis are another aspect that needs to be considered in this regional context and the corridor's future. The SARS nCov-19 virus transformed Pakistan into a vulnerable country and increased the tensions in its already fragile health system. Just by mid-April 2021, the amount of deaths attributed to this virus in the country were more than 16453i. The consequences of the pandemic are still unclear. Still, in a context of regional instability, China could represent a safe haven, especially in 2021, which marks the 70th anniversary of the establishment of diplomatic relations between the two nations.

\section{The Iranian Search for Leadership}

The rich history of Iran has been linked to regional political and economic leadership for centuries. In this sense, the Persian nation's current political economy and international relations have been oriented to reinforce the country's ancestral role. The BRI project and the new bridges that the CPEC entails, such as the foreseen construction of the awaited gas pipeline of $2775 \mathrm{~km}$ between Pakistan and Iran, after India pulling out of the project, have led China filling the gap (Raza 2019, p.48). The CPEC (China-Pakistan) rapprochement is seen as an opportunity for new and renewed leadership after decades of structural change that have not been translated into real economic and political benefits. In 40 years, the country has experienced one of the most important political changes in the Middle East and possibly in the entire Muslim world. The 1979 revolution against the reign of Mohammad Reza Shah Pahlavi ended two centuries of monarchy, and as Javidan and Dastmalchian (2003) explained, it affected different structures of the country at a political, economic, religious and cultural level: "from a tradition-breaking and West-leaning culture to the world's largest theocracy; from a society of rapid economic growth and slower societal change to a society of economic decline and a dizzying pace of societal change; from a country most concerned about its global image, particularly in the West, to a country known in many parts of 
the world as militant, fundamentalist, hateful, and isolated" (Javidan and Dastmalchian 2003, p. 127).

The country political image has also brought unexpected economic results. Despite the fact that it is one of the largest oil producers, with an estimated 90 billion barrels of proven oil reserves and the second-largest natural gas reserves in the world, the country has experienced sluggish economic performance and has been struggling with an unemployment rate of $25 \%$ since early 2000 (Ibid:127). However, what has had a more significant impact on both the country's political and economic development has been its contested nuclear program. Its nuclear aspirations have created tensions both at the regional and international levels with severe consequences for its relations with its neighbouring countries and its international alliances, including China. The international community raised alarms (mostly pressured by Israel's concerns) in November 2011 when a new report from the International Atomic Energy Agency (IAEA) alluded to a possible military dimension in Iran's nuclear program. The country's nuclear program led to a series of economic sanctions against the government, contributing to fuel moments of unrest in the Middle East, a regional instability pushed back then by the Arab political revolutions in the Middle East (Rajmil 2012).

\section{China's rapprochement}

The Chinese Iran approach began after the nuclear deal was signed with Iran in July 2015 under the P5+1 agreement or Joint Comprehensive Plan of Action (JCPA), in which China had a crucial negotiator role. The deal appeared to leave behind the logic of nuclear deterrence in the Middle East and let the country with few years of economic release and sanctions relief. However, with the Trump administration and renewed confrontation, acerb dialectics between Washington and Teheran escalated. Things turned back for Teheran, ending with the USA withdrawal from the JCPA in May 2019. With this unexpected course of diplomatic action, sanctions and economic collapse reappeared. In short, economic sanctions restricted Iranian trade, limited foreign investment, weakened the national coin value, and increased levels of inflation. The main reason is related to the gap that the sanctions create between the official and the market exchange rates. Dual exchange rates have a disadvantage for private industries as they cannot compete with government industries. Despite that, the monetary policy of the regime managed to keep inflation to a single-digit level. On the other hand, this made the Iranian economy highly vulnerable to oil price fluctuations (Dastgerdia, Yusofb, \& Shahbazc 2018). 
In this context of international pressure towards Iran, significantly affecting its already weakened economy, it is of interest to examine how China's approach could imply a safe partner for Teheran as it seeks to revive its very weak economy. And as in Pakistan's case, the unexpected economic and social effects of the Covid-19 outbreak also need to be considered. Iran is one of the most hit countries by the COVID-19 pandemic, with more than 67,130 deaths attributed to the virus by mid-April 2021ii.

\section{GDP Cointegration Dynamics}

To support the analysis examining the countries' economic relationship it was considered of interest to implement the Engle and Granger test for Cointegration in combination with the Johansen and Juselius test as these are two well-known models that help examine long-term relationships between variables. The relationship between many economic time series is identified to be difference stationary, and this has been confirmed as being the case for the studied variables in this paper. The analysis included each country's (China, Iran and Pakistan) annual GDP drawn from available data sources (Datastream) spanning over the period 1961 to 2019. The analysis started with the implementation of the Vector Autoregressive Model to help identify the optimal number of lags. As annual data was considered for a total of 54 observations, the Akaike Information Criterion (AIC) was identified as the best approach to ensure an optimal lag selection of the AIC criterion in order to support the analysis of small samples. The outcomes indicated that two lags should be considered in this context. Afterwards, each one of the variables was tested for stationarity with the support of the Augmented Dickey Fuller Breakpoint test indicating that the $\triangle G D P$ for each country was stationary at the $5 \%$ significance level.

The Engle-Granger test is a residual-based test for cointegration based on the implementation of the basic OLS estimation that initially assumes that the variables under study would not be cointegrated. As such, the Engle-Granger test estimates a p-lag augmented regression as outlined below.

$$
\Delta u_{1 t}=(\rho-1) u_{1 t-1}+\sum_{j=1}^{p} \delta_{j} \Delta u_{1 t-j}+\mu_{t}
$$

The Johansen cointegration test is a VAR-based test that considers a VAR of order $p$ that can be represented as follows:

$$
y_{t}=A_{1} y_{t-1}+\cdots+A_{p} y_{t-p}+B x_{t}+\varepsilon_{t}
$$

Where $y_{t}$ is a k-vector based on non-stationary variables of order one indicating an I(1) process. Further details on the implemented tests can be found in the authors' seminal papers (Engle and 
Granger, 1987; Johansen and Juselius 1990). The outcomes from the implemented tests are outlined in tables one and two below.

Table 1: Johansen and Juselius Cointegration Test

\begin{tabular}{|c|c|c|c|c|}
\hline Hypothesized No. of CE(s) & Eigenvalue & Trace Statistic & 0.05 Critical Value & Prob. ${ }^{* *}$ \\
\hline None * & 0.90 & 171.11 & 42.91 & 0.0000 \\
\hline At most 1 * & 0.66 & 62.93 & 25.87 & 0.0000 \\
\hline At most 2 * & 0.24 & 12.92 & 12.51 & 0.0427 \\
\hline
\end{tabular}

*Trace test indicates the existence of 3 cointegrating equations at $5 \%$ significance level

Table 2: Engle and Granger Cointegration Test

\begin{tabular}{|c|c|c|c|c|}
\hline Dependent & tau-statistic & Prob.* & z-statistic & Prob.* $^{*}$ \\
\hline CHINA & -7.674513 & 0.0000 & -36.82991 & 0.0013 \\
\hline IRAN & -4.681037 & 0.0071 & -32.93947 & 0.0041 \\
\hline PAKISTAN & -5.922941 & 0.0002 & -44.91907 & 0.0001 \\
\hline
\end{tabular}

*The single equation test confirmed the existence of a cointegration relationship between

the countries annual GDP at $1 \%$ significance level.

The Johansen cointegration test revealed the existence of three cointegration vectors. The EngleGranger test helped to confirm the results indicating that the countries share a long-run relationship, as illustrated in figure 1 below, reinforcing the idea of a corridor that can lead to potential benefits for every partner. However, the questions that emerges related to imbalances on those benefits and the implications for the weaker patterns.

Figure 1: GDP Performance

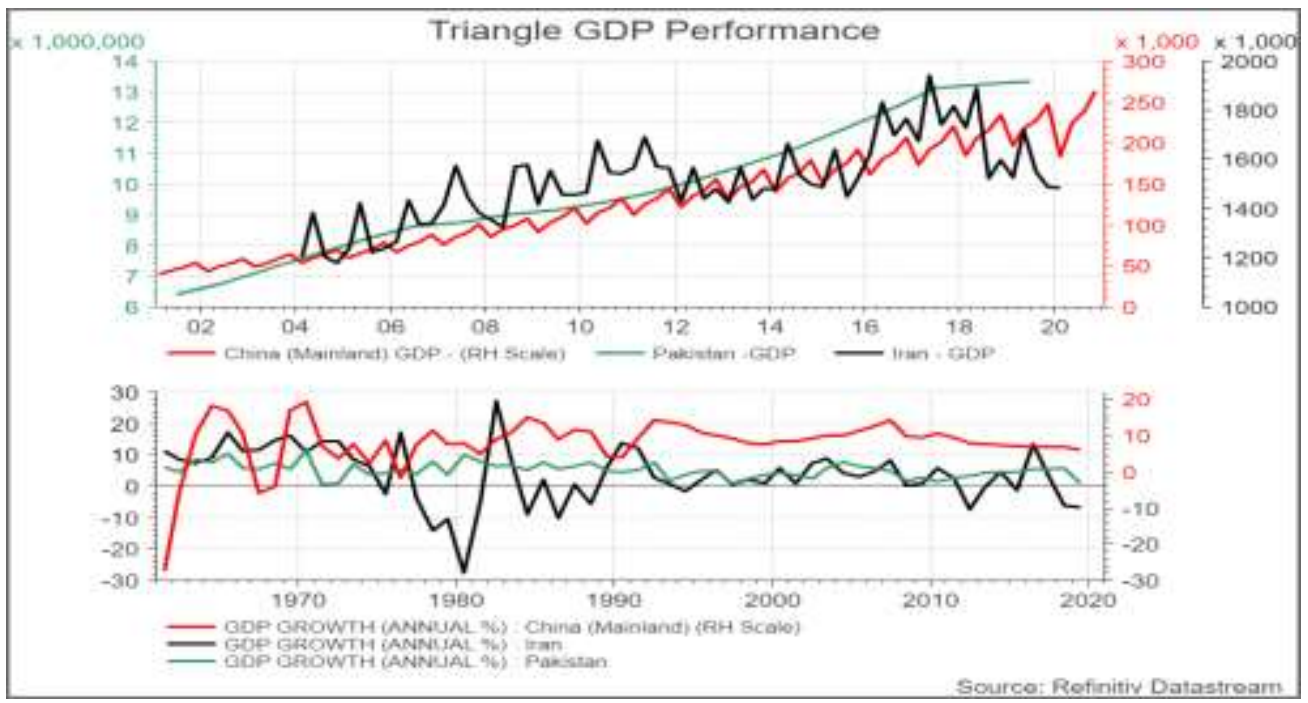

Source: Authors (2020) Data sourced from Refinitiv DataStream 


\section{The Economic Corridor that Could Benefit every Partner}

Iran's and Pakistan's political-economic contexts seem to suggest that an alliance between the three countries through an economic corridor might be feasible in the short-term. This is very much predicated on whether China will be able to make real progress in terms of economic allies, which is itself related to the way Beijing could foster the economic benefits of all the alliance participants. In order to analyse these points, the economic corridor that those countries would create needs to be examined.

China is both Iran's and Pakistan's biggest trading partner; this empowers Beijing, through a soft economic and political approach, to have a more significant influence than any other economy on the nations' short-term economic and trading future. China is also Iran's biggest non-oil importer, and their bilateral trade kept growing standing at US\$37.18 billion in 2017 (Raza 2019, p. 39). Pakistan also shares a sound relationship with China, particularly in economic terms (ibid:40). Moreover, China appears to equally need Pakistan and Iran and one proof of it is the US\$3 billion investment offer that China has made to develop the oil fields in Iran. China's domestic energy problems emerge in this context. The country faces major challenges in securing its energy supply and fostering the transition to a more diversified energy model which is less dependent on heavily polluting coal (Rajmil et al., 2020; Zavadska et al. 2020). This step will help align Iran with the massive energy and infrastructural cooperation between Pakistan and China under the CPEC (Ibid).

If we further dig into the CPEC project, as a possible extension of the existing bilateral trade agreements between China and Pakistan, one could realize that this could influence as well Pakistan-Iran relations. In addition, Pakistan-Iran economic relations have been inconsistent for decades and have not benefitted from their neighboring position (Imtiaz 2019). The signature of the CPEC in April 2015 has enabled the creation of a new era of bilateral relations between China and Pakistan, which, along that of the BRI, are boosting the trade and economic partnership. To this date, President Xi's visited Pakistan to sign various memoranda of understanding (MOUs) with, the then Pakistani President Nawaz Sharif, around different economic investments with a value of 46 billion dollars (Rizwanullah et al 2020). The MOUs included all kinds of economic and trade tools and loans and investments were estimated at a value of $\$ 60$ billion and that will be 
spent to develop a 2,700 km route from Kashgar to Gwadar, Pakistan's seaport, becoming one of its main pillars (ibid). Nevertheless, neither the CPEC initiative nor the already existing China Pakistan Free Trade Agreement (CPFTA), signed in 2006, appears at first sight, not to have created a real trampoline for Pakistan's economic and bilateral trade figures.

Despite some initial projections and estimated figures that were enthusiastically announced during the CPEC launch, Pakistan's economy does not seem to have benefited from having a special deal with the second world's largest economy. There are two main possible factors to explain this weak performance. First, Pakistani policymakers tend to claim they did the most at that time of the negotiations, but they refuse to accept the reality that projections made at that time were not realistic. A second issue to be considered is that private-sector representatives and exporters' lobbies in the country also apparently failed (Ahmed, 2020). One way or the other, it is incontestable to claim that current figures show an unequal economic and bilateral trade relationship between the two countries. The evolution and the expected outcome of bilateral trade and political improvement has not translated into a direct benefit equation. By looking into the most recently published government figures of the two past years and acknowledging the general economic effects of the Covid-19 pandemic, the equation is unfavorable to the Pakistani economy (see Table 3). Exports to China represent just a 6.53\% of total Pakistani exports in 2020 with a decrease of $1,58 \%$ of the total share of exports of the Pakistani trade, equivalent to a decrease of 2490,91 Millions of Rs (Pakistan Bureau of Statistics 2020).

Table 3. Pakistani Cumulative Exports

\begin{tabular}{|c|c|c|c|c|}
\hline \multirow[t]{2}{*}{ Countries } & \multicolumn{2}{|c|}{ July 2020} & \multicolumn{2}{|c|}{ July 19} \\
\hline & $\begin{array}{ll}\text { Value } & \text { (in } \\
\text { Millions Rs) }\end{array}$ & \% Share & $\begin{array}{ll}\text { Value } & \text { (in } \\
\text { Millions Rs) } & \end{array}$ & \% Share \\
\hline USA & 67912,05 & 20,35 & 53287,75 & 17,79 \\
\hline UK & 28887,85 & 8,66 & 22337,36 & 7,46 \\
\hline Germany & 25852,70 & 7,75 & 17692,05 & 5,91 \\
\hline China & 21803,85 & 6,53 & 24294,76 & 8,11 \\
\hline Netherlands & 19148,95 & 5,74 & 14482,70 & 4,83 \\
\hline TOTAL & 333665,06 & 100,00 & 299588,31 & 100,00 \\
\hline
\end{tabular}

Source: Pakistan Bureau of Statistics (Government of Pakistan 2020 iii). 
Conversely, by looking into Pakistani imports, China keeps its first place in terms of Pakistani main importing countries (Table 4).

Table 4. Pakistani Cumulative Imports

\begin{tabular}{|c|c|c|c|c|}
\hline \multirow[t]{2}{*}{ Countries } & \multicolumn{2}{|c|}{ July 2020} & \multicolumn{2}{|c|}{ July 19} \\
\hline & $\begin{array}{ll}\text { Value (in } & \text { Millions Rs) }\end{array}$ & $\%$ Share & $\begin{array}{ll}\text { Value (in } & \text { (in } \\
\text { Millions Rs) } & \end{array}$ & \% Share \\
\hline China & 169537,00 & 27,67 & 149188,55 & 25,30 \\
\hline $\begin{array}{l}\text { United Arab } \\
\text { Emirates }\end{array}$ & 73800,64 & 12,05 & 70514,01 & 11,96 \\
\hline Indonesia & 34305,29 & 5,60 & 19695,23 & 3,34 \\
\hline Saudi Arabia & 27343,50 & 4,46 & 24807,00 & 4,21 \\
\hline USA & 26298,52 & 4,29 & 20687,37 & 3,51 \\
\hline TOTAL & 612663,23 & 100,00 & 589738,56 & 100,00 \\
\hline
\end{tabular}

Source: Pakistan Bureau of Statistics (Government of Pakistan, 2020iv). 
In other words, by looking at the above figures, there is a clear inverse correlation of shares between imports from China and exports from Pakistan to China. In 2020, Pakistani imports from China are 4.2 times the value of the Pakistani exports to the same country. The proportion for 2019 is smaller, at 3.1., implying a deterioration in Pakistan's terms of trade.

Furthermore, it is important to understand China's relevance to Iran's complicated economic situation. Beijing is amongst the few countries that have overlooked the USA sanctions and that granted exemptions to the USA continuing thus to import oil from Iran. Teheran has found in the Asian giant a big relief to the economic sanctions that have tightened the Ayatollah's regime since Trump came into power. As a reaction, the understanding between the two countries is not confined only to the economic field; it includes security and energy aspects directly impacting upon the two countries' bilateral economic and trade dynamics. This rapprochement is not recent as it was already manifested during Xi Jinping's visit to Iran in 2016; it has been accelerated with the USA's shared confrontational policies over the past few years, especially during President Trump's term in office. This situation culminated with the leaking by the New York Times of a 25 year cooperation program deal between Iran and China, drafted in July $2020^{v}$. The agreement, still to be officially approved and ratified, would be an economic and security partnership that would include billions of dollars of Chinese investments in energy and other sectors. It would also expand the Chinese involvement in finance and telecommunications projects. In exchange, China would receive a regular - according to Iranian sources -, well discounted, supply of Iranian oil for the next 25 years (Farnaz \& Steven 2020).

By looking into the recent economic and trade performance between China and Iran, an asymmetry can also be found in the exports and imports figures of the two countries. Current economic trade official data offered by China's customs website show that 2020 data followed a declining sequence ${ }^{v i}$. In this, Chinese customs data show that trade with Iran continues to fall, especially as China is buying less oil from Iran. This could be taken as a sign that Iran is not on Beijing's top list of investment destinations. According to the official statistics posted by China's General Administration of Customs (GACC), trade with Iran went down by $41 \%$ to $\$ 6.4$ billion in the first five months of 2020 , compared to the $\$ 10.9$ billion registered during the same period in 2019. This decrease shows a $62 \%$ reduction in Chinese imports from Iran, although Chinese exports to Iran remained stable, falling just 1\% to \$3.69 billion in the first five months of 2020 (Ghasseminejad 2020). Without any doubt, and regardless of the general decline in exports and imports from China to Iran, one of the top products in the base bilateral trade relation is the 
Chinese import of Iranian crude. Here, the effect of sanctions has been present, and there has been a general decline of Iranian production, which in OPEC data seem to show a clear pattern of decrease (Figure 2). There is the possibility that Iran could overpass sanctions by storing unsold oil in tankers at sea, with data showing as well that Iran could find end users for this oil despite the effect of general sanctions.

Figure 2 - Iran's crude Oil production:

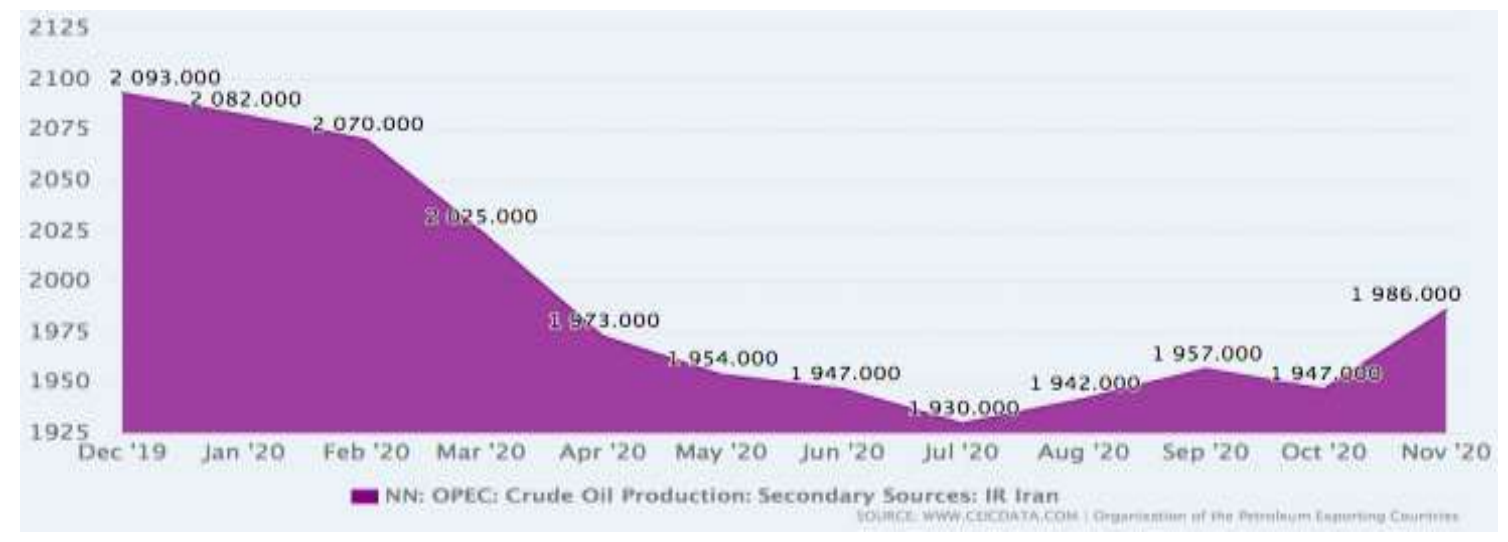

Source: CEIC(2020 website)

\section{Challenges to the China-Pakistan-Iran-China Alliance}

This paper's final insights seek to present a clear image of China's challenges while engaging with both countries in its plan to consolidate the BRI and to maximise its benefits. In other words, how to keep the economic relationship with two key allies and how to overcome internal and external challenges to these alignments. As such, this section offers a geopolitical analysis of the remaining obstacles to the political and economic stability of both Iran and Pakistan, and of the potential implications for the People's Republic of China. In this geopolitical process, it is clear that one of the main challenges that China faces relates to its goal to expand to central Asia in the background of crises and global instability. To begin with, Iran plays the role of a pivot country in the Middle East based on its controversial nuclear program. The USA position on Iran's nuclear programme has been relatively stable throughout different administrations despite some uncertainty that remains attached to Teheran's nuclear program. Iran has found a deterrent power in its nuclear policy, and as classical deterrence theory explains, the nuclear realm enables it (Brown \& Arnold 2010). Therefore, it is expected that Iran will use the nuclear card as a negotiating force in the short-term to reclaim its power and leadership in the region. 
In late November 2020, this deterrence logics has been seen in the aftermath of the assassination of Mohsen Fakhrizadeh, one of the top scientists behind the Iranian nuclear program. Iran's parliament passed a bill to force the West to return to the Joint Comprehensive Plan of Action (JCPOA) conditions. It could mean a stop to the International Atomic Energy Agency (IAEA) inspections increasing Iran's enrichment of uranium, and revitalising the Fordow plant, among others (Motamedi 2020). As Iran views the JCPOA as its main source of negotiation, likewise, hardliners in the region, Israel, Saudi Arabia, and the Gulf countries, are worried about the United States joining the JCPOA without any further Iranian concession. Three main reasons as published by a complete political analysis published in The Economist in early December $2020^{\text {vii }}$ sum up this situation: 1) the Treaty is viewed sceptically due to its timeline and as the previous arms embargo expired in October 2020 while other restrictions in equipment acquisitions will soon end; 2) Iran's military sophistication is already advanced in comparison to the 2015 negotiation framework; 3) Iran's leadership and influence in the region have been advanced during the years of the political "calm" during the years of the JCPOA.

For all the reasons mentioned above, the Iranian nuclear program and nuclear diplomacy will undoubtedly influence the region's economic stability, as well as oil exports to China, and the Middle East's geopolitical stability.

Turning to Pakistan, Pakistan's underlying and ongoing tension with its neighbour India could have a devastating effect on China's investment plans. On the one hand, the ongoing conflict of Kashmir, with its origin in the Indo-Pakistan war of independence in 1947, led to a disputed territory situation between India and Pakistan. Its current occupation and sovereignty is split since 1963 among three states, Pakistan, India, and China. Over time, China has adopted different policies regarding this issue. Nevertheless, both Indian occupied Kashmir and Pakistan occupied Kashmir are of China's interest (Bukhari \& Parveen 2014). Since then and for decades, Kashmir has played a key role in an intermittently logics of conflict between Pakistan and India, evolving to nuclear deterrence politics and war games. On the other hand, the China Pakistan rapprochement will indeed create some geopolitical tensions within an already tense triangle of interests. This is related to India's perception of the emerging Sino-Pakistan alliance as a challenging one due to its connectivity to the region. China and Pakistan's ambitious projects as the Gwadar Port and the CPEC represent a direct factor to China's energy and political stability (Sandeep \& Bawa, 2019). Both countries "have several reasons for their animosity with India such as boundary issues, Islamic fundamentalism, regional power politics, India's rising power status, 
global leadership aspirations, growing Indo-USA relations, Afghan and Balochistan problems" (Ibid:179).

These regional dynamics involving nuclear politics, deterrence, military, economics, and political influence games will probably be one of the main challenges stabilizing the CPEC project. How these dynamics could easily trigger a regional border conflict was seen in mid-November 2020. In a press conference held by the foreign minister of Pakistan, Shah Mahmood Qureshi with military spokesman Major-General Babar Iftikhar, it was announced that they possessed evidence of Indian involvement in what was called "terrorist" activities targeting Pakistan. The announcement highlighted dangerous activities coming from Afghan soil, targeting Chinese interests in its southern province of Balochistan, referring primarily to Chinese development projects that have emerged with the China-Pakistan Economic Corridorviii. The claims were denied both by India and Afghanistan portraying the fragility that the alliance entails.

Lastly, when looking into Iran and Pakistan relations, as it has been seen, the economic ties of both countries have been inconsistent and could be improved. However, when looking into the political relations of the two neighbours, the non-linear political relations has been consistent. On one hand, Iran was the first country to recognize Pakistan's independence from the British Empire in 1947. This could be seen of how relevant the two countries are in each other's history. On the other hand, recent political history has brought some distance between the two countries, especially after the initiation of the so-called USA war on terror in Afghanistan and within the religious Pakistan-Saudi Arabia rapprochement (Ahmed \& Akbarzadeh 2018). In addition, the traditional Pakistani foreign policy neutrally, which should maintain a balance between the country and the publically Iranian-Saudi hostilities seems to favour Saudi Arabia before Iran (Ibid 2020). This is another added political challenge to the existing fragile economic and trade equilibrium that the CPEC entail.

\section{Conclusions}

China has played an ambitious card with its BRI to gain political and economic momentum. Nevertheless, as with any political leadership project, it needs stable allies to ensure that projects are successful and that they contribute to sustainable economic growth. With this aim in mind, this paper has investigated two specific BRI actors that have in recent years embarked upon an ambitious rapprochement move to China: Iran and Pakistan. For different reasons, some being political, others economic, and others still military, both countries have looked for Beijing 
assistance to grow and overcome political tensions that threaten their economic growth and development. The econometric analysis performed in this paper shows that the three countries have an economic potential for strengthening links in the future, although trade figures still talk of a un-balanced relationship to the detriment of the non-Chinese counterparts; this moves away from the idea of a partnership that will generate a balanced contribution to the involved countries.

Iran, is identified as one of the countries that will have a more significant say in the Middle East and central Asia's political future, but its current position is quite complex due to its isolation, and as such its government is in seek of help. The years of the Trump administration have proven to be devastating for Teheran's economy and its foreign relations along with its country branding image are in the international spotlight. Without any close expectations that the nuclear games of the country will ease in the near future, China could prove to be a safeguard to export its goods while the country is challenged by a Middle East that brings closer Israel, Saudi Arabia and the Gulf countries while leaving Iran more and more isolated in the region. China is also aware of the key geographic place that Iran has in securing oil supply and therefore it is of Beijing interest to gain momentum in any diplomatic dispute involving the country.

The other big regional actor present in the Chinese plan for the upcoming years is Pakistan. With a critical structural economic shortfall since its independence in 1947, Pakistan has suffered from in-depth crises for decades and has failed to gain momentum in exporting to neighbouring countries and profit from the existing bilateral economic agreement with China since 2015. Therefore, the CPEC project is an ambitious plan that will facilitate Chinese access to Pakistan's energy sources and new infrastructures built in exchange. Nevertheless, as the data shows, Pakistan's gains from Beijing economic relations m still seem unimpressive and raises concerns regarding the country's ability to benefit from the partnership. Lastly, the political context will indeed have a more significant say. The underlying tension with India, amid the Kashmir dispute and in front of this new eclipsing Sino-Pakistani friendship, could trigger diplomatic tensions between Pakistan and India, and even China.

To conclude, when putting the cards on the table of the Chinese plans in Pakistan and Iran, the economic benefits seem clear. Nevertheless, the economic and trade figures still talk of a unbalanced profitable relation to the detriment offer the non-Chinese counterparts; this moves moving away from the idea of a partnership that will generate a balanced contribution to the involved countries. In addition, both Pakistan and Iran face political and military axes with foreign 
countries that risk their political and economic stability in the near future. In both cases, the two countries have a common entangled crisis that involves deterrence and militar politics. How this situation will affect the BRI initiative and the Chinese plans for those territories is still, by today not clear, as blurry does as any long-term crisis that involves fragile and complex international alliances. 
References

Aized, T., \& al, E. (2017). Energy security and renewable energy policy analysis of Pakistan.

Renewable and Sustainable Energy Reviews, http://dx.doi.org/10.1016/j.rser.2017.05.254.

Ahmed, S. H. (08 de June de 2020). Improving trade balance with China. The express tribune.

Ahmed, Z. a. (2018). Understanding Pakistan's Relationship with Iran . Middle East Policy, 25(4), 86-100.

Ahmed, Z. \& Shahram A. (2020) Pakistan caught between Iran and Saudi Arabia, Contemporary South Asia, 28:3, 336-350, DOI: 10.1080/09584935.2020.1779181

Ashraf, J. (2017). String of Pearls and China's Emerging Strategic Culture. Strategic Studies, 37(4), 166-181. doi:10.2307/48537578

Aslam, S. (1998). The Underground Economy and Tax Evasion in Pakistan: Annual Estimates (1960-1998) and the Impact of Dollarisation of the Economy. The Pakistan Development Review, 37(4), 621-631. Retrieved April 10, 2021, from http://www.jstor.org/stable/41261074 Brown, A., \& Arnold, L. (10.1177/0047117810377278 de 2010). The Quirks of Nuclear Deterrence. International Relations, 24(3), 293-312.

Bukhari, S. W., \& Parveen, T. (2014). China's approach towards Kashmir conflict: A viable solution. Journal of Professional Research in Social Sciences, 14-30.

CEIC oil production charts, accessed in December, 2020:

https://www.ceicdata.com/en/indicator/iran/crude-oil-production

Dastgerdia, H. G., Yusofb, Z. B., \& Shahbazc, M. (2018). Nexus between economic sanctions and inflation: a case study in Iran. Applied Economics, 50(49), 5316-5334.

Engle and Granger (1987) Co-Integration and Error Correction: Representation, Estimation, and Testing. Econometrica, Vol55(2), 251-276.

Esteban, M. (2016). The China-Pakistan Corridor: A transit, Economic or Development Corridor? Strategic Studies, 36, 63-74. 
Farnaz, F., \& Steven, L. M. (11 de July de 2020). Defying U.S., China and Iran Near Trade and Military Partnership. The New York Times.

Imtiaz, Amber (2019). "Pakistan-Iran relations: economic and political dimensions." Perspective, March 2019 edition. A

Johansen, S., \& Juselius, K. (1990). Maximum likelihood estimation and inference on cointegration with application to the demand for money. Oxford Bulletin of Economics and Statistics, 52, 169-221.

Junaid, A. (2017). String of Pearls and China's Emerging Strategic Culture.

Javidan, M., \& Dastmalchian, A. (2003). Culture and leadership in Iran: The land of individual achievers, strong family ties, and powerful elite. Academy of Management Perspectives, 17(4), 127.

Khan, A., \& Khalil, S. (2018). The real size of underground economy: a Case of Pakistan. Pakistan Journal of Applied Economics, 91.

Khan, M. (2014). Pakistan-Iran-China triangle: A game changer in the region? Dialogue, 116-138. Motamedi, M. (2 de December de 2020). Iran to further limit nuclear commitments: What's next? Aljazeera(https://www.aljazeera.com/news/2020/12/2/iran-to-further-limit-nuclearcommitments-whats-next).

Ogunlana, M. A. (2006). Good project governance for proper risk allocation in public-private partnerships in Indonesia. International Journal of Project Management, 24(7), 622- 634. Pakistan Bureau of Statistics (Government of Pakistan). Table of Pakistani Exports, 2020 accessed at: http://www.pbs.gov.pk/trade-tables Pieper, M. (2019). An Iran Nuclear Deal Without the United States? Chinese, European, and Russian Interests and Options After the US Withdrawal from the Joint Comprehensive Plan of Action. Contemporary Issues in International Political Economy.

Rajmil, D. (2012). El nuevo equilibrio de poderes en Oriente próximo. Obtenido de Instituto Español de Estudios Estratégicos: 
http://www.ieee.es/Galerias/fichero/docs_opinion/2012/DIEEEO40-

2012_Nuevo_equilibrioOrienteProximo_DRajmil.pdf

Rajmil, D., Morales, L., and Andreosso-O'Callaghan, B., (2020) "China's Ecological Civilization: Geopolitical and Geo-economic Insights?" in Bernadette Andreosso-O'Callaghan, San Dzever, Jacques Jaussaud and Robert Taylor. (eds.) Sustainable Development and Energy Transition in Europe and Asia. Volume 9 - Sustainable Development and Energy Transition in Europe and Asia SET Coordinated by Chantal Ammi, ISTE Publishing Knowledge, Wiley, pp.145-

159. Civilization: Geopolitical and Geo-economic Insights.

Raza, F. (2019). Prospects for Pakistan-China-Iran Trilateral Cooperation: Opportunities and Challenges.. Strategic Studies, 39(3), 1-10.

Rizwanullah, M., Zhi, L., Ali, M., Yuan, Y., Hou, D., \& -, Z. (2020). Role of CPEC in Enhancing Mutual Trust and Regional Integration: Across OBOR Countries. International Journal of Business and Social Research, 10(2), 18-27. doi:https://doi.org/10.18533/ijbsr.v10i2.1284 Sandeep, S., \& Bawa, S. (13 de June de 2019). Geopolitics of ports: Factoring Iran in India's counterbalancing strategy for "Sino-Pak Axis". Journal of Eurasian Studies(https://doi.org/10.1177/1879366519850712).

Sumit, G., Et, \& Al. (2019). India, Pakistan, and the Kashmir dispute: unpacking the dynamics of a South Asian frozen conflict. Asia Europe Journal, 17.

Valasai, G. D., Uqaili, M. A., Memon, H. R., Samoo, S. R., Mirjat, N. H., \& Harijan, K. (2017).

Overcoming electricity crisis in Pakistan: A review of sustainable electricity options. Renewable and Sustainable Energy Reviews, 72, 734-745.

Wu, S., \& Pan, Q. (2019). Financial cooperative potential between China and Belt and Road Countries. Emerging markets finance and trade, 55(14), 3295-3310.

Zavadska, M., Morales, L., and Andreosso-O'Callaghan, B., (2020) "Is China's Dependency on Coal a Threat to Its Economic Development?" in Bernadette Andreosso-O'Callaghan, San Dzever, Jacques Jaussaud, and Robert Taylor. (eds.) Sustainable Development and Energy 
Transition in Europe and Asia. Volume 9 - Sustainable Development and Energy Transition in

Europe and Asia SET Coordinated by Chantal Ammi, ISTE Publishing Knowledge, Wiley, pp.23-

42.

' Data offered by the COVID-19 Dashboard by the Center for Systems Science and Engineering (CSSE) at Johns Hopkins University (JHU). Accessed on the 20th of April 2021 at: https://coronavirus.jhu.edu/region/pakistan

ii Data offered by the COVID-19 Dashboard by the Center for Systems Science and Engineering (CSSE) at Johns Hopkins University (JHU). Accessed at: https://coronavirus.jhu.edu/region/iran (20th April 2021).

iii Accessed on April 2021 at the following link: http://www.pbs.gov.pk/trade-tables

iv Accessed on April 2021 at the following link: http://www.pbs.gov.pk/trade-tables

"NY times article "Defying U.S., China and Iran Near Trade and Military Partnership", accessed at: https://www.nytimes.com/2020/07/11/world/asia/china-iran-trade-military-deal.html

vi Information offered by the official Chinese Customs website, accessed on December 2020: http://english.customs.gov.cn/Statics/e506a1cd-d147-49cd-ab43-4c45e117c2d3.html

vii Full articled published ad accessed by The Economist, on the 5th December 2020:

https://www.economist.com/middle-east-and-africa/2020/12/05/joe-biden-wants-to-re-enter-thenuclear-deal-with-iran

viii Pakistan says it has evidence of India sponsoring attacks:

https://www.aljazeera.com/news/2020/11/14/pakistan-says-it-has-evidence-of-india-sponsoring-attacks 